\title{
The Development of a Business Information System in the Company of a Bathroom Equipment Manufacturer: a Case Study
}

\author{
Petr Sodomka, Hana Klčová and Jiří Kř́ž, \\ Center for inVestigations into Information Systems (CVIS), Department of Informatics, Faculty of \\ Business and Management (FBM), Brno University of Technology (BUT) \\ Kolejní 2906/4, 61200 Brno, Czech Republic
}

Correspondence should be addressed to: Petr Sodomka; petr.sodomka@cvis.cz

Received date: 7 March 2014; Accepted date: 3 July 2014; Published date: 31 December 2014

Copyright @ (2014. Petr Sodomka, Hana Klčová and Jiř́ Kříž . Distributed under Creative Commons CC-BY 3.0

\begin{abstract}
The case study describes the development of a business information system in the company which - after several years from the successful implementation of the ERP system of the world-known origin - had to decide to buy another ERP solution that would meet its requirements for covering a network branch abroad. The study shows how important it is during the selection of an information system and its supplier to use the long-term strategic plan as a basis and not to forget any important aspect. After several years this can mean the implementation of a new project and increasing the costs instead of effective development of the original solution and savings from the scope of purchasing another system.

Keywords: Information system; ERP system; ERP concept; strategic management; implementation project; strategic position; SBU (Strategic Business Unit); bathroom equipment; production cycle; SCM (Supply Chain Management)
\end{abstract}

\section{Introduction}

The Roltechnik company is solely a Czech company, engaged in the production of shower enclosures, classic and whirlpool tubs. In 2012, its sales exceeded CZK 400 million; it employed 104 people. As such, it ranks as a medium-sized firm. The company offers a broad portfolio of products for all types of customers. Only in the area of shower enclosures it produces over 3,000 variations in ten product series. In recent years, the company has constantly developed its product ranges, and due to the competitive pressure and market requirements, it intends to diversify its products also in the future.

David Nový, the Economic Director of the company, comments on this topic: "A few years ago we for example did not deal with any hydro-massage systems; we only had a few basic models of baths. Today we are one of the top manufacturers of hydro-massage systems, and their sale constitutes 20\% of 
the product portfolio. Currently we register more than 20 thousand stock items, a twofold increase over 2005."

The company supplies its products to the wholesale network of specialized dealers and to chains, such as OBI or Baumax. End customers account for a very small part of the turnover, and the company does not actively build this channel because the factory is far from the motorway network. Export accounts for $50 \%$ of sales of the company; its products head mainly for the Visegrad and Baltic countries. The sales volumes are very volatile as the export countries find themselves in different phases of the economic cycle because of the crises.

\section{Research Methodology}

Every year, the Center for inVestigations into Information Systems conducts research of the Czech ERP market, the integral part of which is the processing of case studies in the form of qualitative enquiry and the technique of a projection interview with the staff responsible for investments in the IS/ICT in the relevant organization. In 2005-2013, the authors conducted more than 130 such case studies in manufacturing, trading and service enterprises in the Czech and Slovak Republics.

The authors used the following literary sources as the theoretical foundation for the application of the research methodology: Gill, Johnson, 1991, and Pavlica, 2000. For processing the case studies, they then used the information from the book Case Study Research (Yin, 2003). The theoretical foundation for the realization and evaluation of implementation projects is based on extensive practical experience of the Center for inVestigations into Information Systems, and on the long-term study of the following professional sources: Voříšek, 1997, Davenport, 1998, Molnár, 2001, Basl, 2002, Olson, 2003, Olson, Chae, Sheu, 2005, Smejkal, Rais, 2006, Laudon, Laudon, 2006, Schwalbe, 2007, Pour, Gála, Šedivá, 2009.
The authors used and studied theoretical knowledge concerning implementation projects also from the studies of analytical companies focused on the global and Czech markets, such as Deloitte Consulting, 2000, Accenture, 2001, Hestermann, Anderson, Pang (Gartner), 2009.

When processing the case study, the authors also relied on publications dealing with supplier chains, management of business information science, knowledge management and corporate performance management from the following authors: Fischer, Hammond, 1994, Lee, 2002, Chopra, Meindl, 2004, Pour, 2008, Voříšek, Jandoš, Feuerlicht, 2011, Buřita, Hagara, Ondryhal, 2012, Chvátalová, Hřebíček, 2012, Kocmanová, Hřebíček et al., 2013.

\section{Two ERP systems and their use in the company}

\section{Strategic background and definition of key requirements}

The production cycle of the company begins with the prognosis of sales for one year, prepared by the sales department. The strategic materials and the materials with long lead times are purchased on its basis; this cannot be done without the support of an information system, which calculates forecasts and calculations every night. A production plan is then compiled according to the requirements of the sales department, and a production order is run. Thanks to the system, the management has the information about the predicted production, work in progress as well as finished products, so the customers can be informed of the status of their orders.

Out of $80 \%$, sales consist of serial products, which are manufactured to stock (basically as safety stock) as there are in significant demand. Thanks to the growing demands of the market, large series of dozens of pieces have changed into mini-series including only a few pieces. This change has required a complete alteration of the system in the setting for production planning. The remaining part of the orders includes customer orders. The 
manufactured products are delivered to the shipping warehouse. The shipping is done on the basis of the delivery plan, covered by several contract carriers.

\section{The main aspects of implementation}

"Our original system was already technically and morally overcome and did not provide the necessary information," comments on the decision to change the information system David Nový, and adds: We mainly missed an ability of forecasting, planning and making accurate calculations. Without these functions of the system, we would not be able to further expand the product portfolio and face growing competition."

The company therefore announced a tender in 2003 for the information system and its supplier, which took place in three rounds. First of all, individual interviews were held, discussing the submitted bids. This was followed by presentations, after which two solutions were shortlisted. After reference visits, the company management opted for the solution Visual Enterprise (today's Infor10 ERP Express) by the Gemma Systems company on the basis of the following criteria:

- It is a global system that is able to support the company growth in the long term.

- The strength of Visual Enterprise lies in the support of the planning and managing of the production and logistic process including strategic purchasing, with a wide range of customization.

- The bid showed a favourable price/performance ratio.

- Reference visits to factories taken care of by Gemma Systems convinced the client that it would not be a problem to deploy the system and to customize it to specific requirements.

After the lapse of five years, David Nový judges the selection of the ERP system as follows: "If we compared - from the current point of view - the options of the Infor10 ERP Express system and the SAP Business One system, which we use in foreign subsidiaries, then it would have probably been better to implement this simple solution by SAP and to have the production module developed by order. For this, however, it is necessary to know how the production module should work, which we did not know at the time of purchasing Infor10 ERP Express. To have a production management application developed by order without an existing base is - in our opinion - a path that does not lead to the desired target."

\section{Problems with people}

The management felt that the staff is not very much in favour of the change. Engaging people to the project was therefore based on a directive decision and determination of target bonuses. David Nový commented: "We wanted to give some order to the change of the system and avoid a discussion that would bring a disproportionate number of requirements to the project. After some time, however, we realized that this was not an ideal way of working with people. Without stimulating their own active efforts, it is difficult for the company management to avoid bad decisions."

"On the other hand, it needs to be said that the employees in the position of key users were not resolute enough. Passively absorbing information from the supplier, they did not think about whether the given advice and procedures were suitable for the use in the situation of our company."

"We can say that the communication problems were not only within our organization, but also between us and the supplier. Its consultants are undoubtedly very experienced practitioners, but I believe they should have regulated us more as a customer and given us more space to consider some steps," concludes his comments David Nový. 
Table 1: The main information about the implementation project Infor10 ERP Express in Roltechnik (prepared by us)

\begin{tabular}{|c|c|}
\hline ERP system & $\begin{array}{c}\text { Infor10 ERP Express (formerly Infor ERP Visual, Visual } \\
\text { Enterprise) }\end{array}$ \\
\hline Implementation partner & Gemma Systems \\
\hline Period of implementation & 7 months (January 2004 - August 2004) \\
\hline User training & In $2010-2012$, with the support of EU funds \\
\hline Number and type of users & 21 working simultaneously \\
\hline Server operation system & MS Windows Server \\
\hline Database platform & MS SQL Server \\
\hline Architecture & Two-layer client/server, using the technology of the thick client \\
\hline Processes covered by ERP system & $\begin{array}{c}\text { Economics; buying, selling and internal logistics; human } \\
\text { resources management is covered by the local application RON } \\
\text { Software }\end{array}$ \\
\hline Project benefits & $\begin{array}{c}\text { Increased inventory turnover by } 22 \% \text {; savings in personnel } \\
\text { costs; improvement of production management and logistics } \\
\text { including strategic purchasing; monitoring the profitability of } \\
\text { products and customers }\end{array}$ \\
\hline
\end{tabular}

The company management expected that after the implementation of the system, everything would work much better. But the opposite was true. It was necessary to run in the system and to test new work procedures. In the course of hectic processing of daily agenda, it was not possible to immediately absorb all the knowledge from the training. Rapid anticlimax therefore came soon and the employees began to look at the project with undisguised pessimism.

"It took quite a long time to remove the critical view of the employees and for the system to start bringing a visible added value. From experience we know that on the day when the full operation starts, the realization of the expected benefits does not start automatically," comments David Nový on project pitfalls.

Given this experience, the company continuously, during the use of the information system Infor10 ERP Express, organized training for its key and end users. For example, in 2010 - 2012 it delivered training by means of the project
Improving the Adaptability of Employees and Competitiveness of Enterprises, which was supported by EU funds under the Operational Programme Human Resources and Employment.

\section{Measurable benefits and savings of personnel costs}

We can talk about the benefits only after a longer period of the system operation. From measurable indicators, we can mention in particular the reduction of inventories and increase of their turnover $(22 \%)$. We also achieved the savings of personnel costs (four employees). However, the employees were not laid off; they were transferred to implement new projects, which were established as the growth of the company required.

The system is undoubtedly strongest in production planning and management. Although it does not have an advanced management superstructure or the CRM module, it also provides valuable managerial information. It helps especially the evaluation of the profitability of 
products and excluding unprofitable products. If the loss is seen with regard to a part which is too costly, it is possible to get its replacement by another supplier by means of the information system.

David Nový adds: "In our experience, it is evident that the benefits from the implementation of the information system take effect only after a longer time. If someone says to you that you will recognize the change already after three months, then do not believe him. The maximum change which you can see is the new form of an invoice."

Forced upgrade, which did not bring any benefit

In 2009 , the company had to change to a new version of the system as the supplier stopped supporting the previously used version. Experience gained during the first implementation project helped to ensure that the upgrade went quite easily.

"The actual upgrade unfortunately did not bring any benefit to our company, on the contrary; we had to spend a significant amount and solve problems with custom modifications. After this experience, we therefore added to the contract with the supplier a condition of the supplier's obligation to support the newly deployed version of the system for a precisely defined time period also in the future," comments David Nový on this necessary step.

Investment in innovations and further development of the solution

Even after several years of operation, the company still sees room to improve the system. And this is a reason why it invests one million CZK in its development every year. Almost immediately after launching the system into full operation, it was decided to purchase a managerial superstructure that was missing in the new ERP system. The Info21 company came with an offer of the Lighthouse solution, which was implemented two months after the deployment of the ERP system and has been used till now. This simple managerial superstructure provides all necessary information necessary for supporting decisions mainly in the form of reporting.

Another important innovation project was the implementation of EDI communication, which in 2010 was used already by five out of ten major customers. The scope of communication varies by wholesalers. The most advanced wholesaler covers the whole order cycle by the EDI system, including delivery notes and invoices. Other wholesalers use the electronic data exchange only for sending orders. The results of implementing EDI, however, are clear:

- The system is able to handle 20-30 orders or invoices daily, which resulted in saving one employee.

- $\quad$ Today 20-30\% company turnover is ensured through EDI communication.

The electronic data exchange works through the VAN operator; the customization in the ERP system was programmed by the employees of Gemma Systems.

How to extend the information system to foreign branches

Two years ago, the managers of Roltechnik began to address the issue of how to efficiently obtain information for decisionmaking from foreign subsidiaries. Because Infor10 ERP Express did not meet the basic requirement, i.e. the localisation in the countries in which the company had its branches, it was necessary to choose a different solution. At that time the Info21 company was looking for the first reference customer to deploy SAP Business One. Since the Roltechnik managers had good experience with the delivery of the Lighthouse managerial solution and also preferred a supplier who would already know the business processes and needs of the company, an agreement was made with Info21 for the implementation of the smallest of the SAP products. 
At the beginning of the implementation project, custom adjustments and settings of the application in the CR were carried out. In Poland the deployment of the system then took only four days including the debugging of errors. In the Hungarian branch the implementation was somewhat delayed - similar problems occurred as with the implementation of Infor10 ERP Express six years previously. Some employees were constantly looking for mistakes and postponing the sharp start of the system. It was therefore necessary to make some personnel changes, after which SAP was started within one week.

For each branch it is typical that it runs the ERP system locally on its own server. At night, replication then takes place to the servers in the Czech Republic. The users can thus either browse one day old data with an instantaneous response, or connect to foreign branches and work with the current data. All local instances are further linked through EDI, and can thus transmit orders and invoices.

The logistic processes in all branches operate exactly in the same way, only the accounting is done individually in accordance with legal requirements of each country. A managerial system is separately deployed over each individual instance and is used to monitor key indicators.

The extension of the information system to foreign branches brought about the simplification of processes, immediate availability of data for decision making and - above all - a general overview, which makes the management of the entire company easier.

Table 2: The main information about the implementation of SAP Business One in Roltechnik (prepared by us)

\begin{tabular}{|c|c|}
\hline ERP system & SAP Business One \\
\hline Implementation partner & Info21 and two local partners abroad \\
\hline Period of implementation & $\begin{array}{c}\text { One-month preparation, the actual implementation 4 days } \\
\text { (September 2008 - December 2008) }\end{array}$ \\
\hline Countries covered & Poland and Hungary \\
\hline Number and type of users & 9 named users \\
\hline Server operation system & MS Windows Server \\
\hline Database platform & $\begin{array}{c}\text { MS SQ Server } \\
\text { Architecture }\end{array}$ \\
\hline Processes covered by ERP system & $\begin{array}{c}\text { Economics; buying and selling logistics; human resources } \\
\text { management }\end{array}$ \\
\hline Project benefits & $\begin{array}{c}\text { Unification and simplification of processes in all branches; } \\
\text { making the business more transparent; instant availability of } \\
\text { data for decision making; simplicity of the solution }\end{array}$ \\
\hline
\end{tabular}

\section{Conclusion}

In the future the company would like to extend the functionality of the information system by the SCM area. According to the management ideas, the suppliers could view the system and prepare in advance the capacity for the preparation of sub- supplies. On the basis of the confirmed order they could then more flexibly respond to the request of the manufacturer, while the entire agenda would be implemented directly in the information system. 
When considering the expansion of the information system, the responsible personnel take the following proposition as the basis: The greater the implied unpredictability of the demand, the readier for action the supplier chain should be. To achieve high performance, the companies should direct the competitive strategy (and the subsequent implied unpredictability) and the strategy of the supplier chain (and the subsequent readiness for action) to the zone of the so-called strategic position (Chopra, Meindl, 2004).
Defining a strategic position is based on the assumption that the company does not transact business with multiple SBUs. The competitive strategy of the company is based on the differentiation of the product portfolio on a broad segment. The demand and sub-supplies can be characterized as predictable. At the same time, the demand for production exceeds the offer and the processes in the chain are oriented as "push". The implementation of the SCM functionality aims to promote competitive strategy and increase the level of automation of the replenishing cycles (Sodomka, Klčová, 2010).

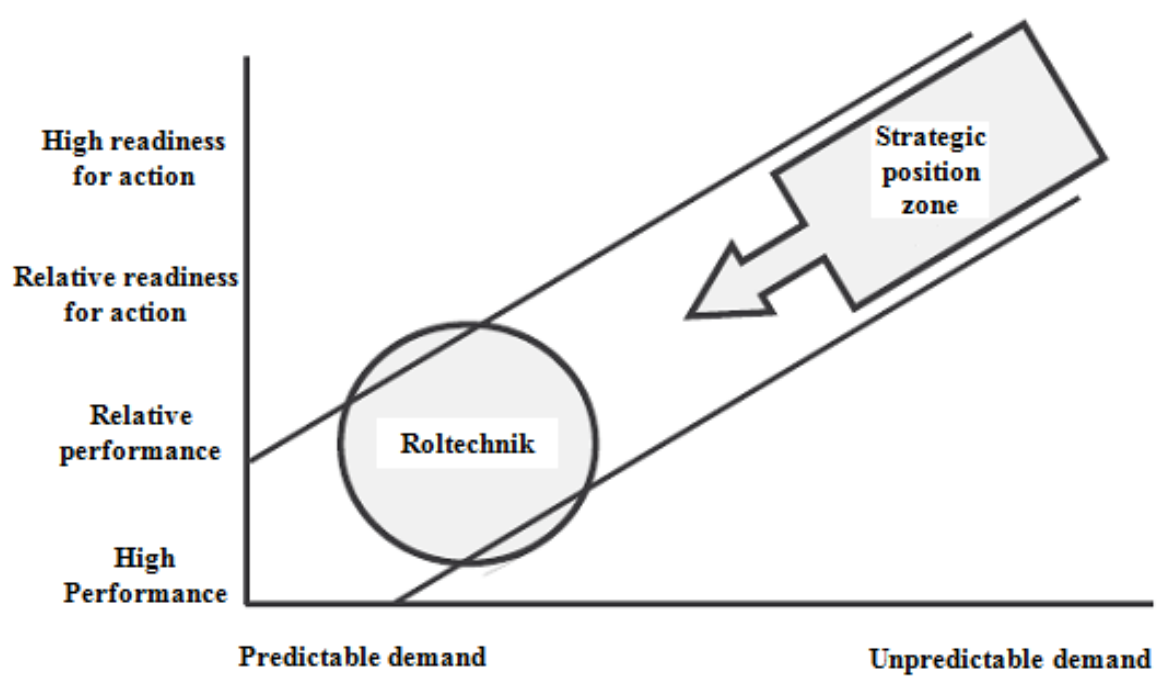

Fig. 1: Defining the strategic position of Roltechnik (prepared by ourselves)

The strategic position was defined as the relation between the high up to relatively high performance and predictable demand. The chain is therefore tasked to satisfy the demand while outlaying the lowest possible costs and to shorten lead times without increasing the costs. If the company focused on creating a chain with high readiness for action, the production would likely become disproportionately more expensive, which - despite the current excess of demand - could lead to the loss of customers.

Changes in the hierarchy of business strategies to achieve the strategic position are seemingly simple, but in reality it is a very difficult issue. Achieving consistency between the competitive strategy and the SCM concept is especially restricted by:

- $\quad$ The combined range of products and different customer target groups

- Product life cycle

- Competitive changes over time

Due to the ten-year development of the business informatics based on the ERP category systems, the company is sufficiently experienced that its intention can be evaluated as feasible and beneficial to increase competitiveness of the entire supply chain to which it belongs. An 
appropriate strategy should be set in direct dependence on the strategy of the entire company. It is also necessary to have a good connection with other processoriented strategic concepts (for the ERP area in particular) and with the competitive strategy for the given SBU, which - in this case - means the company as a whole.

\section{References}

1. Accenture. (2001) Hodnota podnikových informačních systémů $v$ České republice. Interní studie společnosti Accenture

2. Basl, J. (2002) Podnikové informační systémy. Grada Publishing, Praha

3. Buřita, L.; Hagara, L.; Ondryhal, V. (2012) Knowledge Systems for User Applications and Education. In 7th IEEE International Conference on Knowledge, Information and Creativity Support Systems (KICSS 2012). Melbourne, Australia, Proceedings, pp. 1-6

4. Chvátalová, Z.; Hřebíček, J. (2012) Modelling of economic phenomena and dependences for corporate sustainable performance. In I. J. Ramík, D. Stavarek. 30th International Conference on Mathematical Methods in Economics. Karvina, Silesian Univ Opava, Sch Business Adm Karvina, pp. 350-354

5. Chopra, S., Meindl, P. (2004) Supply Chain Management (Second Edition). Upper Saddle River, NJ: Pearson Education

6. Davenport, T. H. (1998) Putting the Enterprise into Enterprise Systém. Harvard Business Review. July-August, 1998, no. 3, pp. 121-131

7. Delloitte Consulting (2000). ERP's Second Wave - A Global Research Report.

8. Fischer, M. L., Hammond, L., et al. (1994) Making Supply Meet Demand in an Uncertain World. Harvard Business Review, vol. 72, no. 3, pp. 83-93
9. Gill, J., Johnson, P. (1991) Research Methods for Managers. P. Chapman Publishing, London

10. Hestermann, C.; Anderson, R. P.; Pang, C. (2009) Magic Quadrant for Midmarket and Tier 2-Oriented ERP for Product-Centric Companies. Gartner RAS Core Research Note G00163386

11. Kocmanová A.; Hřebíček, J.; Dočekalová, M.; Hodinka, M.; Hornungová, J.; Chvátalová, Z.; Kubálek, T.; Popelka, O.; Šimberová, I.; Topolová, I.; Trenz, O. (2013). Měření podnikové výkonnosti. Littera, Brno.

12. Laudon, K. C.; Laudon, J. P. (2006) Management Information Systems (9th edition). Pearson Prentice Hall, New Jersey

13. Lee, H. L. (2002) Aligning Supply Chain Strategies with Product Uncertainties. California Management Review, vol. 44, no. 3, pp. 105-119. ISSN 0008-1256

14. Molnár, Z. (2001) Efektivnost informačních systémů. Grada Publishing, Praha

15. Olson, D. L. (2003) Managerial issues of ERP systems. McGraw Hill/Irwin, New York

16. Olson, D. L.; Chae, B.; Sheu, C. (2005) Issues in multinational ERP implementation. International Journal of Services and Operations Management, vol. 1, no. 1, pp. 7-21

17. Pavlica, K. et al. (2000) Sociální výzkum, podnik a management. Ekopress, Praha

18. Pour, J. (2008) Performance and effects of corporate informatics. In IDIMT2008: Managing the unmanageable. Jindrichuv Hradec: 16th Conference on Interdisciplinary Information Management Talks. Publisher: Universitatsverlag Rudolf Koglstr, Linz, Austria, Book Series, Schriftenreihe Informatik, vol. 25, pp. 53-61

19. Pour, J.; Gála, L.; Šedivá, Z. (2009) 
Podniková informatika (2. přepracované a aktualizované vydání). Grada Publishing, Praha

20. Schwalbe, K. (2007) Řízení projektů v IT, kompletní průvodce. Computer Press, Brno.

21. Smejkal, V.; Rais, K. (2006) Řízení rizik ve firmách a jiných organizacích. Grada Publishing, Praha

22. Sodomka, P., Klčová, H. (2010) Informační systémy v podnikové praxi. 2. aktualizované a rozšířené vydání.
Computer Press, Brno.

23. Voříšek, J. (1997) Strategické řízení informačního systému a systémová integrace. Management Press, Praha

24. Voříšek, J.; Jandoš, J.; Feuerlicht, J. (2011) SPSPR Model - Framework for ICT Services Management. Journal of Systems Integration, vol. 2, no. 2, pp. 310

25. Yin, R. K. (2003) Case Study Research: Design and Methods (3rd edition). Thousand Oaks, Sage Pub, Inc. 